\title{
A Review on War and Peace Journalism Paradigm
}

\author{
Yanwen Wang,
}

\author{
${ }^{1}$ University of Edinburgh, Edinburgh, UK \\ *Corresponding author. Email: guanghua.ren@gecacademy.cn
}

\begin{abstract}
Previous studies proposed an effective model to examine media's behaviour in conflict reporting--war and peace journalism paradigm, which consists of a series of dimensions to analyze news coverage. It indicated that media using more war journalism would escalate the conflicts and the media using more peace journalism would reduce the conflicts. This paper mainly combs the relevant research on War and Peace Journalism Paradigm, as well as the comparative research of different media systems, with particular attention to the media reports of China and the United States. Based on this review, a new research will be devoted to summarizing the comparison of different media systems, the dynamics of war and Peace News models and their performance in different political backgrounds, as well as the news reporting models and their impact on the countries of origin and response. At the same time, the study will also predict the correlation between the performance of different media and the change of public opinion on both sides.
\end{abstract}

Keywords: War and peace journalism, Paradigm, Media Systems.

\section{INTRODUCTION}

The rapid expansion of social media enables its users to have more direct access to news, but the traditional mainstream media still maintain its influence, have a larger readership, and establish reliability and authority. Traditional media continue to play an important role in shaping the public's view of events[1]. Meanwhile, "cross-cultural comparison" is very important to understand how different news systems affect public opinion[2].

As Tewksbury \& Scheufele put, the audience's perceptions, attitudes and beliefs of an issue can be influenced by how the story is framed[3]. In a similar vein, Chong and Druckman argue that framing in news could facilitate a process for people to conceptualize an issue along particular lines and reshape their thinking[4]. Hallin proposed news framing plays an important role in wartime, which mirrors the connection between politics and media coverage[5]. Some experts also examined how politicians cast their influence upon public opinions by exploiting media framing[6]. For example, news media can be used to survey public opinion polls and advocate policies during an election campaign[7]. Hallahan also noted that news framing functions as an essential tool of power to determine whose view of the world would prevail[8]. However, when it comes to foreign policy and national security, Lawrence manifested that media coverage is less independent and always in line with political appeals [9].

This paper hopes to sort out the relevant research results, in order to provide theoretical guidance for further discussion of the application of American media and Chinese media in the practice of war and peace journalism.

\section{WAR AND PEACE JOURNALISM}

Galtung argued that journalists play an important role in maintaining world peace[10]. There are two categories in conflict news reporting: peace journalism and war journalism. The former is nonpartisan, covering all sides and focusing more on ordinary people, intending to solve conflicts and call for peace; The latter is the opposite. It emphasizes violence, act as the government's propaganda tool and speak on behalf of the elites, aiming to make its home country the winner. According to Gouse et al., no research taking communist countries as examples has been done to study peace and war journalism since Galtung published his study in 1998[11].

Many useful models could be applied to explain the international news coverage in US media. Most of the previous studies focused on how the public's perception 
of international news was shaped by a high proportion of elite sources in the media coverage. Herman and Chomsky have proposed a propaganda model to examine the way US media report international news and the reasons for their behaviours[12]. Herman argued that news media function as a propaganda tool of the government as they emphasize elite information and are consistent with the dominant ideology, which for US media is anti-communist[13]. The indexing hypothesis introduced by Bennett indicated how news coverage displays a variety of voices in the society[14], and relevant research has shown that elites' opinions are more influential than other sources[15]. Furthermore, the cascading activation model suggested by Entman in 2003 revealed how interpretative frames were created and disseminated from the government to the elites, the news organizations and the public, it also demonstrated how information get passed on from the lower to a higher class. However, there are limitations of these models, they could not illustrate the relationships between news media behaviour and escalation or reduction of the international conflicts.

The war and peace journalism practices could fill in the gap. It analyses the performance of news media in international conflicts and reveals the significance of news sources, Galtung \& Ruge indicated that conflict is a major theme in international news coverage[16]. Conflict is an occasion for development by "being imaginative, creative, transforming the conflict so that the opportunities take the upper hand" [17]. War coverage was defined as the " low road" of journalistic practices because it stresses "violence, war and winners." Peace coverage, however, was deemed as a journalist following the "high road" as it focuses on the peaceful transformation of the conflict[18]. Galtung brought up the concept of peace journalism to support peace culture and reconciliation[19]. It has challenged the conventional way of conflict reporting. He deemed peace journalism and war journalism as two competing frames. This viewpoint was supported by Entman and Scheufele[20][21], who related the peace journalism concept with framing theory--to interpret a news event in a specific way to the audience. Galtung implied that peace journalism is superior to war journalism as it requires the news media to be more proactive and nonviolent in conflict reporting to reduce it rather than escalate it or act as observers[19]. Additionally, Lynch indicated that peace journalism advocates a more "comprehensive and complex" way to cover stories instead of the traditional and simplistic way[23]. It aims at preventing "one-dimensional" conflict reporting as well as encouraging a "culture of peace " and keeping nonpartisan to include all sides[24]. According to Nohrstedt \& Ottosen, amid the outbreak of violent conflicts, international norms and professional ethical standards could be established and promoted by peace journalism reporting[25]. Inspired by peace journalism, Howard suggested journalists "be sensitive" to conflict reporting, they should facilitate dialogues among different parties to avoid stereotypes and stay accurate, fair, balanced and responsible[26]. As mentioned by Neumann \& Fahmy, peace journalism practices emphasize solutions rather than disputes, displaying long-term impacts rather than short-term issues, collecting viewpoints from the wider public rather than government elites, and expressing in careful language rather than oversimplified or "dichotomous terms that pit good against evil" [27]. On the contrary, war journalism features its reactive nature of conflict reporting, focusing on the differences in all sides, advocating violence as the resolution and sometimes even resulting in more disputes.

Some previous studies have discovered Western news media tend to employ war frames when covering regional conflicts, while the local news reports favour peace frames. For instance, in the news coverage of the 2008 - 2009 Gaza War and the civil war in Sri Lanka, Fahmy and Neumann analysed images from leading Western news organizations, and they found that war frames (images showing material damage, casualties, military drills, and paramilitary actions) have a higher proportion than peace frames (visuals depicting peaceful demonstrations, assistance and support efforts, negotiations and summit meetings) in total[27].

Over the past several decades, professional critics and activists have preferred peace journalism over war journalism due to the media's function as a catalyst and influence moderator. However, as many as the existing studies that support peace journalism, this ideal has also received criticisms. Hanitzsch noted that peace journalism overestimated journalists' power in peace maintaining[28]. Many constraints exist in their work and peace journalism advocates transfer the duties of the government and the military to the news media. Therefore, he advised the journalists to reveal the conditions of their coverage and think critically about the sources in order to be more transparent and reflexive. Differently, Ha, et al. argued that transparency and critical views can be achieved provided that journalists recognise the limitations of news sources so that they will strive for more diversity[29]. In addition, news coverage usually contains both war and peace features because of the dual nature. More focus on nonviolence and peace items than war items forms peace journalism practice, which leads the public to aspire to a more peaceful end of the conflict[30].

\section{COMPARING MEDIA SYSTEMS}

Siebert, Schramm, and Peterson identified Four Theories of the Press in different countries according to their different political and philosophical purposes: 1) 
the Authoritarian theory ( "the press functioned from the top down” ); 2) the Libertarian theory ( the press is considered as a partner to find the truth); 3) the Social Responsibility theory, which emphasizes the responsibilities of media, high-quality information and professional journalists; 4) the Soviet Communist theory, which suggests mass communication is an instrument to serve the government while the Social Responsibility theory regards the mass communication as a civil service instead of an instrument[31]. Severin and Tankard proposed that the US media follows the social responsibility theory which requires the media to undertake social responsibilities. Chinese media needs to be supportive of the government's political actions so it conforms to the Soviet totalitarian theory[32].

To compare the differences in news coverage between the US and China, we need to know their journalistic conventions and media systems. According to Josephi, the US press system is regarded as a libertarianism model, while the Chinese media is acknowledged as a resemblance to the Soviet communist model[33]. Hallin and Mancini have claimed that a 'more nuanced' approach is needed to compare media systems, they pointed out four criteria to describe the connections between media and a country's political systems:1) media market, 2) journalistic professionalism, 3)state intervention, 4)political parallelism, which refers to how much "major political divisions" are reflected in the media system in society[34]. Based on these criteria, North American and European media systems were categorized as the following: 1) Western Europe and North America--the North Atlantic or liberal model; 2) Northern and Central Europe--the Democratic Corporatist Model; 3) Southern Europe--the Polarized Pluralist Model. Nevertheless, de Albuquerque has noted the limitation of Hallin and Mancini's theory[35]. It can only explain the situations in Western countries where competitive and stable political systems enable media systems to be related with, but neglect different situations in non-western countries. So he added two criteria: 1)political competitiveness, 2) stability to examine the link between media systems and the political environment.

Chinese media system didn't fall into Hallin and Mancini's three categories above. According to Luo, its media system follows the Soviet Communist theory[36]. As a single-party political system, the Chinese Communist Party takes charge of media content censoring. Unlike in western countries where media act as vehicles to spread the public voice, Chinese media, particularly the party press, serves as the mouthpiece of the government and a propaganda instrument to promote the official ideology and strengthen state control. Luo also indicated that authoritarianism is reflected in the Chinese media system as well because it prioritises and stresses national interests in news coverage.
As Hallin and Mancini's three categories implies, the US media system belongs to the liberal model, the characteristics of which are early commercialization of newspaper, weak state intervention and the marginalization of party, religions, trade unions and non-commercial media[34]. To demonstrate objectivity, fact-oriented discourse always comes with a politically neutral stance. The commercialization at heart is incompatible with political partisanship. Hardy claims that media systems in the liberal model should allow a democratic free world by limiting the power of the state and leaving more discretion to the market[37]. According to McChesney, the origin of American journalism can be dated back to the 17th century, but the modern journalistic concepts of non-partisanship and objectivity didn't come into being until the 20th century[38]. Kaplan argued American journalism has followed the pattern set by World Wars which reinforced a national identity. In news coverage that used a war frame, objectivity had never actually outweighed partisanship, it only transferred the focus on national conflicts to international ones[39]. Additionally, the fact that US media is mostly profitdriven and pursuing sensationalism has intensified this journalistic behaviour [38].

In addition, Chinese mainstream culture has been dominated by Confucianism for over two thousand years. The deep-rooted Confucianism upholds a hierarchical societal structure and requires people to obey and respect the authorities as subordinate to maintain a stable society[40]. Therefore, a core value of Chinese culture is collectivism, as Steele and Lynch noted, collective demands are the priorities and always come before Chinese people's individual needs. On the contrary, the US mainstream culture advocates individualism, which prioritizes individual feelings and needs. Unlike collectivism, individualism puts selfinterests and independence in the first place, and any interference with individual freedom and interests from the state or other institutions are deemed inappropriate and intolerable[41].

Krumbein claimed that culture, ideology and dominant national discourses have largely shaped news framing and coverage to be consistent with the political systems and public opinions[42]. $\mathrm{Lu}$ gave further evidence by noticing that the relationship between China and the US portrayed by media has been shifted from "military allies" to "ideological enemies" [43]. From which we can see that the change in countries' national interests and cultural environment orients the media framing. This conclusion was also supported by Chang, Wang, and Chen's comparative study which explored the broadcast news in each country, they noted that social norms and cultural values will determine the media interpretation of domestic and foreign affairs, the way Chinese and US media cover international stories have been largely influenced by 
their different ideologies and national interests[44]. They often compete for international discourse power by defining the issue with their own media framings. The previous study by Chang, Wang, and Chen found Chinese media included more stories in the US than its American counterpart, which revealed an unbalanced flow of information. With the politics and cultural norms affecting news reporting, it remains a mystery how Chinese and US journalists practice the war-peace journalism paradigm to frame the US-China tensions during the coronavirus pandemic. McGoldrick and Lynch's conducted a four-country laboratory experiment to explore how the audience responds to war-peace journalism news coverage on TV[45]. They found that the audience who received the information interpreted in the peace journalism frame favours nonviolent solutions to the conflict more than those who received information presented in the war journalism frame.

\section{CONCLUSION}

By combing the above relevant research results, this paper will help to further explore the application of Chinese and American media in the practice of war and peace journalism. However, very little research has studied how the war and peace journalism model applies in a communist country, and no research based on the

"New Cold War" has been found. But the how the recent conflicts in the Covid-19 pandemic between the US and China reflect this model remain undiscovered. In the future, a research based on this review hopefully fills the gap by offering insights on the application peace and war journalism model to examine different news media's behaviour under different media systems, regimes and political contexts. And we also wish to divide the US-China conflicts into several stages, especially focusing on the Covid-19 era. Under these time frames, future research will employ war and peace journalism model to find out media in which country is more inclined to war style and which one is more inclined to peace style. The research will also explore how media interpretations correlate with public opinion and foreign policies, as well as gives brief explanations related to the then political contexts. Most importantly, the research will set out a research direction by posing a hypothesis which will be tested by applying the war and peace journalism model. If the model proves effect, then it will show the wide applicability of this model in different media systems, and the correlation between public opinion and reporting style can be justified. This progress will also shed light on some possible instructions on how to promote peace journalism reporting style, to achieve a more peaceful and stable global environment.

\section{REFERENCES}

[1] Veneti, A., Karadimitriou, A. and Poulakidakos, S., Media Ecology and the Politics of Dissent: Representations of the Hong Kong Protests in The Guardian and China Daily, Social Media + Society, 2016, 2(3), pp.1-13.

[2] Brossard, D., Shanahan, J., \& McComas, K., Are issue-cycles culturally constructed? A comparison of French and American coverage of global climate change, Mass Communication \& Society, 2009, 7(3), pp.359-377.

[3] Scheufele, D. A., \& Tewsbury, D., New framing theory and research, In J. Bryant, \& M. B. Oliver (Eds.), Media effects, New York, NY: Routledge, 2009, pp.17-33.

[4] Chong, D., \& Druckman, J., Framing theory, Annual Review of Political Science, 2007, 10, pp.103-126.

[5] Hallin, D. C., "The Uncensored War" : The media and Vietnam, New York: Oxford University Press, 1986.

[6] Semetko, H. A., \& Valkenburg, P. M., Framing European politics: A content analysis of press and television news, Journal of communication, 2000, 50(2), pp.93-109.

[7] Schudson, M., The news media as political institutions, Annual Review of Political Science, 2002, 5(1), pp.249-269.

[8] Hallahan, K, Seven models of framing: Implications for public relations. Journal of Public Relations Research, 1999, 11(3), pp.205-242.

[9] Lawrence, S.V., Perspectives on Chinese foreign policy, 2011. Retrieved from http://www.uscc.gov/sites/default/files/4.13.11Law rence.pdf.

[10] Galtung, J., Peace journalism, Media Asia, 2003, 30(3), pp.177-180.

[11] Gouse, V., Valentin-Llopis, M., Perry, S., \& Nyamwange, B., An investigation of the conceptualization of peace and war in peace journalism studies of media coverage of national and international conflicts, Media, War \& Conflict, 2019, 12(4), pp.435-449.

[12] Herman, E. S., \& Chomsky, N., Manufacturing consent. The political economy of the mass media. New York, NY: Random House, 1988.

[13] Herman, E. S., The propaganda model: A retrospective, Journalism Studies, 2000, 1(1), pp.101-112. 
[14] Bennett, W. L., Toward a theory of press-state relations in the United States. Journal of Communication, 1990, 40(2), pp.103-127.

[15] Althaus, S., Edy, J., Entman, R., \& Phalen, P., Revising the indexing hypothesis: Officials, media, and the Libya crisis, Political Communication, 1996, 13(4), pp.407-421.

[16] Galtung, J., \& Ruge, M. H., The structure of foreign news: The presentation of the Congo, Cuba and Cyprus crises in four Norwegian newspapers. Journal of Peace Research, 1965, 2(1), pp.64-90.

[17] Lynch, J., and Galtung, J., Reporting Conflict: New Directions in Peace Journalism, Queensland, Australia: University of Queensland Press, 2010.

[18] Galtung, J., Peace journalism: What, why, who, how, when, where? Paper presented at TRANSCEND workshop "What are Journalists for?”, Taplow, England, 1998.

[19] Galtung, J., High road, low road: Charting the course for peace journalism. Track Two, CCR, 1998, 7(4), pp.7-10.

[20] Entman, R. M., Framing: Toward clarification of a fractured paradigm. Journal of Communication, 1993, 43(4), pp.51-58.

[21] Scheufele, D.A., Framing as a theory of media effects. Journal of Communication, 1999, 49(1), pp.103-122.

[22] Colbert, A. M., Peace journalism, In C. H. Sterling (Ed.), Encyclopedia on journalism, Los Angeles, CA: SAGE, 2009, pp. 1047-1048.

[23] Lynch, J., Using conflict analysis in reporting: The peace journalism option, Conflict and Peace Forums, 2000.

[24] McGoldrick, A. and Lynch, J., Peace journalism: What is it? How to do it?, 2000.Available at: http://www.transcend.org/tri/downloads/McGoldric k_Lynch_Peace-Journalism.pdf

[25] Nohrstedt, S. A., \& Ottosen, R., Peace journalism: A proposition for conceptual and methodological improvements, Global Media and Communication, 2015, 11(3), pp.219-235.

[26] Howard, R., Conflict-sensitive reporting: State of the art: A course for journalists and journalism editors, Paris, France: UNESCO, 2009.

[27] Neumann, R. and Fahmy, S., Analyzing the spell of war: A war/peace framing analysis of the 2009 visual coverage of the Sri Lankan Civil War in newswires, Mass Communication and Society 2012, 15(2), pp.169-200.
[28] Hanitzsch, T., Journalists as peacekeeping force? Peace journalism and mass communication theory. Journalism Studies, 2004, 5(4), pp.483-495.

[29] Ha, L., Yang, Y., Ray, R., Matanji, F., Chen, P., Guo, K. and Lyu, N., How US and Chinese media cover the US - China trade conflict: a case study of war and peace journalism practice and the foreign policy equilibrium hypothesis, Negotiation and Conflict Management Research, 2020.

[30] Lee, S. T., \& Maslog, C. C., War or peace journalism? Asian newspaper coverage of conflicts. Journal of Communication, 2005, 55(2), pp.311329.

[31] Siebert, F., Schramm, W., \& Peterson, T., Four theories of the press, Urbana: University of Illinois Press, 1956.

[32] Severin, W., \& Tankard, J., Communication theories: origins, methods, and uses in the mass media (5th). Longman, 2001, pp.309-318.

[33] Josephi, B., Journalism in the global age: Between normative and empirical, Gazette, 2005, 67(6), pp. 575-590.

[34] Hallin, D. and Mancini, P., Comparing Media Systems: Three Models Of Media And Politics, Cambridge: Cambridge University Press, 2004.

[35] de Albuquerque, A.D., Media/politics connections: beyond political parallelism, Media, Culture \& Society, 2013, 35(6), pp.742-758.

[36] Luo, A., Media system in China: a Chinese perspective, International Communication of Chinese Culture, 2015, 2(1), pp.49-67.

[37] Hardy, J., Western Media Systems, London: Routledge, 2008.

[38] McChesney, R. W., The problem of journalism: A political economic contribution to an explanation of the crisis in contemporary US journalism, Journalism Studies, 2003, 4(3), pp.299-329.

[39] Kaplan, R. L., American journalism goes to war, 1898-2001: A manifesto on media and empire, Media History, 2003, 9(3), pp.209-219.

[40] Sugihara, Y. and Katsurada, E., Gender-role Personality Traits in Japanese Culture, Psychology of Wonwn Quarterly, 2000, 24, pp.309-318.

[41] Steele, L. and Lynch, S., The Pursuit of Happiness in China: Individualism, Collectivism, and Subjective Well-Being During China's Economic and Social Transformation, Social Indicators Research, 2012, 114(2), pp.441-451. 
[42] Krumbein, F., Media coverage of human rights in China, International Communication Gazette, 2015, 77(2), pp.151-170.

[43] Lu, X., From "ideological enemies" to "trategic partners": A rhetorical analysis of U.S.-china relations in intercultural contexts, Howard Journal of Communications, 2011, 22(4), pp.336-357.

[44] Chang, T. K., Wang, J., \& Chen, C., The social construction of international imagery in the postcold war era: A comparative analysis of US and Chinese national TV news, Journal of Broadcasting \& Electronic Media, 1998, 42(3), pp.277-296.

[45] McGoldrick, A., \& Lynch, J., Audience responses to peace journalism: Merging results from a fourcountry research study. Journalism Studies, 2016, 17(5), pp.628-646. 